\title{
ASSESSMENT OF TECHNICAL CONDITION DEMONSTRATED BY GAS TURBINE BLADES BY PROCESSING OF IMAGES FOR THEIR SURFACES

\author{
OCENY STANU LOPATEK TURBINY GAZOWEJ \\ METODĄ PRZETWARZANIA OBRAZÓW ICH \\ POWIERZCHNI
}

\author{
Józef Błachnio, Jarosław Spychała, Wojciech Pawlak, Artur Kułaszka \\ Instytut Techniczny Wojsk Lotniczych, \\ e-mail: jozef.blachnio@itwl.pl,jaroslaw.spychala@itwl.pl \\ wojciech.pawlak@itwl.pl, artur.kulaszka@itwl.pl
}

\begin{abstract}
The paper presents a non-destructive test method that makes it possible to assess condition of gas turbine blades based on the analysis of their images acquired in visible light. The results of high temperature's influence on the condition of blades are revealed. The direct relationship between the temperatures of blades and discoloration of their surfaces is demonstrated. These relationships have been found out by the analysis of images in the form of first order statistical parameters derived wherefrom. The studies revealed alterations of the blade superalloy microstructures entailed by the effect of high temperature, hence the results in the form of first order statistical parameters could be correlated against alterations of the blade superalloy microstructures. Eventually, the variations of first order statistical parameters as well as variations of the blade superalloy microstructures could be determined as the functions of temperature. These relationships make it possible to assess how much the alloy microstructure is altered due to high temperature merely by discoloration of the blade surface. The innovative method can be used for in-flight evaluation of the superalloy overheating for gas turbine blades in operation.
\end{abstract}

Key words: gas turbine, blade, discoloration, heat resistant alloy, microstructure

Streszczenie: $W$ artykule przedstawiono nieniszczaca metode oceny stanu topatek turbiny gazowej, opartej na przetwarzaniu obrazów ich powierzchni $w$ świetle widzialnym. Zaprezentowano wyniki badań oddziaływania wysokiej temperatury na topatki. Wykazano zwiqzki pomiędzy temperatura wygrzewania topatek, a zmiana barwy ich powierzchni. Zwiazki te reprezentowano przez wyniki analizy obrazów w postaci parametrów statystyki pierwszego rzęu. Przedstawiono zmiany mikrostruktury nadstopu topatek pod wptywem działania wysokiej temperatury. Wyniki w postaci statystyki pierwszego rzędu skorelowano $z$ wynikami zmiany mikrostruktury nadstopu lopatek. W rezultacie otrzymano zależności parametrów statystyki pierwszego rzędu oraz zmiany mikrostruktury nadstopu topatek w funkcji temperatury. Zależności te sa przydatne do oceny zmian mikrostruktury w wyniku oddziaływania temperatury $z$ wykorzystaniem zmian barwy powierzchni topatek. Zaprezentowana metoda może shuzyć do oceny stanu przegrzania nadstopu podczas eksploatacji topatek turbiny gazowej.

Stowa kluczowe: turbina gazowa, łopatka, zmiana barwy, stop żaroodporny, degradacja mikrostruktury 
Assessment of technical condition demonstrated by gas turbine blades.... Ocena stanu topatek turbiny gazowej metoda przetwarzania obrazów ....

\section{Introduction}

Operation of gas turbines is associated with various defects of their components. The own studies and reference literature sources $[1,3,4,6]$ demonstrate that most of defects is entailed by malicious operation (maladjustment) of various components and subassemblies that collaborate with the turbine, chiefly the combustion chamber and the exhaust jet when the turbojet engines are the point. Only a small number of defects to turbine subassemblies are caused by the defects of materials, manufacturing or technologies.

The frequent reason for defects lies in adverse temperature alterations of the blade temperatures - overheating, thermal fatigue - caused by excessive temperature or prolonged effect of heat as well as aggressive properties of exhaust gases $[1,4]$ (Fig. 1).
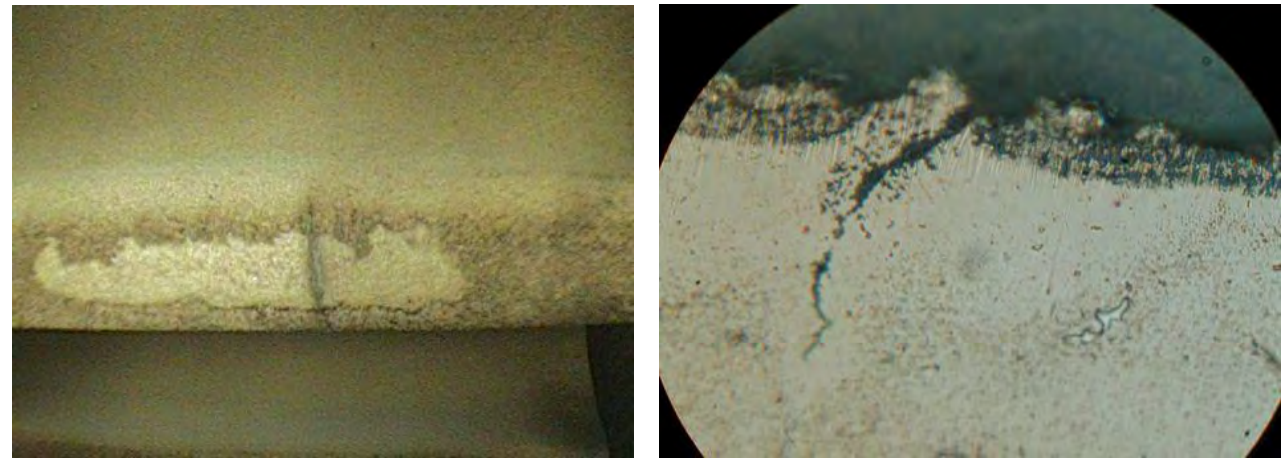

Fig. 1. Example image of turbine blade decohesion [1, 4]

Overheating of the blade materials results from exceeding the maximum average temperature of exhaust gas as well as uneven distribution of temperatures down the turbine perimeter. One of the possible reasons for uneven distribution of temperature downstream the turbine is improper atomization of fuel due to deposition of contaminations in fuel injectors.

Overheating of blade material leads to faulty operation of the gas turbine, or may even be a reason for avionic accidents with dramatic consequences. The deposits are usually removed by a major overhaul of the turbine, which is associated with huge expenses. The cost of the engine overhaul exceeds the price of a single blade by the magnitude of several thousands.

The decision about the need to have the engine overhauled is taken by a diagnostic engineer who uses various instruments, e.g. a videoscope to inspect the turbine interior and assess the condition of hard accessible components. The condition is evaluated on the basis of recorded images of areas subject to comparison against the pattern images for operable and inoperable images of corresponding blade areas within the turbine. The reliability of the assessment depends on a series of factors, i.e. skills and experience of the diagnostic engineer, the applied diagnostic 
procedures and methods, soundness of diagnostic instruments, ambient conditions of the experiment, etc. Nevertheless, it is always a subjective assessment of the diagnostic engineer burdened by the risk of faulty decision. The assessment of the diagnostic engineer can be verified only by means of destructive examinations, where the blade under tests is subjected to the microstructure analysis across the polished microsection.

There are still no unbiased criteria for unambiguous assessment with the use of non-destructing methods of the blade material being affected by the overheating conditions. The idea of the completed studies consisted in application of the digital image processing and analysis to snapshots of blade surfaces captured in visible light. The proposed method should enable to establish the relationship and interconnections between parameters of the digital images acquired for surfaces of gas turbine blades in visible light and parameters of the blade microstructures in order to trustworthy evaluate alterations of the blade status in a non-destructive manner.

\section{The non-destructive method for assessment of gas turbine blades status based on processing of their images captured in visible light}

Non-destructive examinations aimed at determining status of gas turbine blades chiefly employ the method of visual inspection. When assisting optical instruments are used for investigations, in particular a videoscope, viewing of turbine interiors is possible without the need to disassemble the machine. Acquisition of images recorded in the digital form enables storage and analysis of snapshots by means of computer software.

The technique for acquisition of images, both monochrome and color ones enables continuously more and more wide and easy use of information provided by the recorded images for the diagnostic purposes [3, 6]. From the viewpoint of a diagnostic engineer the important issue is to correctly recognize and identify colours of image components, which frequently is a pretty difficult task. Identification of colour is quite often used for a series of diagnostic procedures and the decision is taken on the basis of the comparison between the colour shades of recorded images and the predefined patterns.

The diagnostic model for computer-aided analysis of signals acquired from surfaces of turbine blades in order to extract the information that is suitable for further analysis comprises the following steps $[2,6]$ :

1) Acquisition of images,

2) Analysis of the image with selection of the Region of Interest (ROI),

3) Conversion into a monochromatic image (greyscale shades)

4) Quality assessment of the image for blade surface

5) First-order statistics (parametrical description of histograms)

6) Analysis of the first-order statistics

7) Verification of results obtained from the analysis and describing the overheating degree of gas turbine blades. 
Assessment of technical condition demonstrated by gas turbine blades....

Ocena stanu łopatek turbiny gazowej metoda przetwarzania obrazów ....

The following assumptions were adopted for the model:

1) All images are acquired under the same conditions and with the same resolution;

2) Illumination - white, dispersed light;

3) No disturbing light, reflected against other surfaces

4) Only new gas turbine blades were used for investigations;

5) Fragments of blades were randomly selected and heated in the oven at presence of kerosene at temperatures of $1123 \mathrm{~K}$ and above with the increment of $100 \mathrm{~K}$;

6) Only variation of chromaticity (waveform amplitude location) were taken into account as the parameter that defines variations of chrominance and luminance demonstrated by the surfaces under test;

7) Images were acquired with use of a videoscope, all images with the same resolution and the same magnification scale, light of the visible bandwidth.

To enable unambiguous description of surfaces some typical areas were selected for test (averaged Regions of Interest - ROI). Then the Matlab software package (Image Processing Toolbox) was used to transform colour snapshots to greyscale images (256 greyscale shades). It was investigated whether the 'black and white' information is sufficient to reflect discolorations caused by heat impact of high temperatures (overheating). The parametrical description of histograms consisted in determination where the maximum value of the amplitude is located (number of pixels with the specific saturation (shade) of the greyscale). The histograms plotted for images of surfaces under tests provide information about the number of pixels with a certain greyscale shade restricted by the selected fragment (ROI) of images. To use the histograms for diagnostic purposes the waveforms that present variations of the maximum amplitude as functions of the temperature are approximated by means of polynomials (splines). Digital images have one specific feature, namely for each image one can plot a histogram, i.e. a graph of frequencies of individual greyscale shades occurrence within the picture (Fig.2).
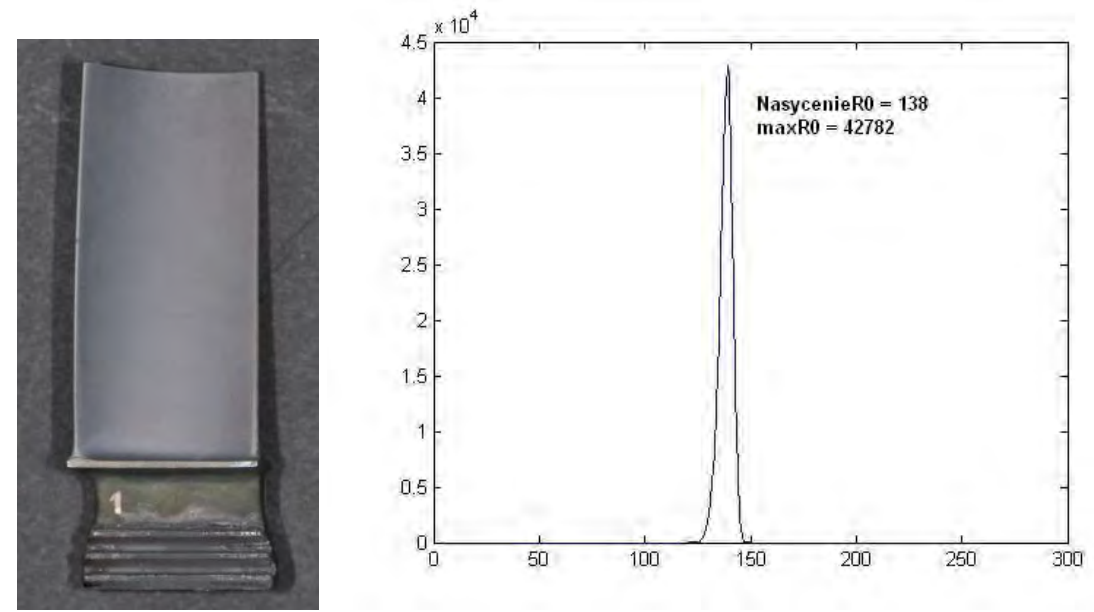

Fig. 2. An exemplary result from the computer-aided spectral analysis of images acquired for blade surfaces 
The images for surfaces of blades made of the EI-867 WD superalloy were acquired both before and after heating in the oven. The snapshots were taken with use of a videoscope on a purposefully constructed test bench, which guaranteed repeatability of test conditions and trustworthiness of test results.

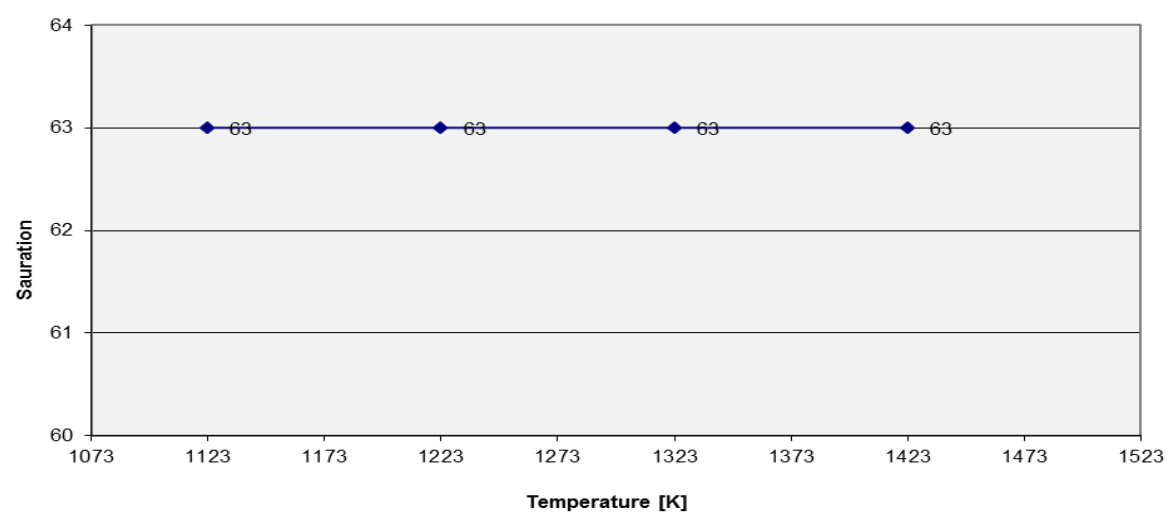

Fig. 3. The values for location of the maximum amplitudes for greyscale saturation measured on surfaces of new blades

Investigation of the first order statistical parameters (parametrical description of histograms) for images of new blades made it possible to reveal identical values of greyscale saturation balance (Fig. 3).

In order to achieve discoloration of blade surfaces similar to the colour of the material observed under regular operating conditions the blades were subjected to heating in an oven at presence of exhaust fumes released by aircraft fuel (Fig. 4).

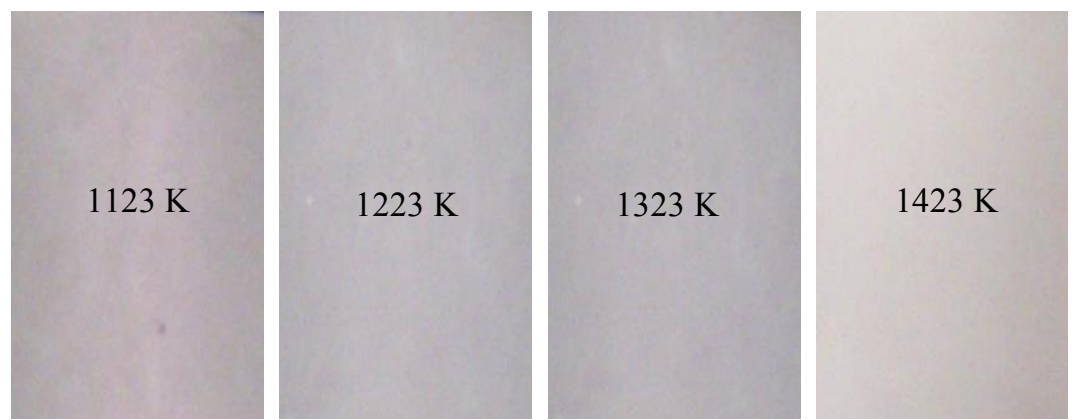

Fig. 4 Images for surfaces of samples taken from the turbine rotor blades selected for parametrical description of histograms (location of the position for the maximum amplitude value of the greyscale saturation balance on the blade surface)

The completed investigation on the first order statistical parameters (parametrical description of histograms) of blade surfaces after heating them at presence of exhaust gas fumes demonstrated monotonic decrease of the amplitude value for the greyscale saturation balance (Fig. 5). 
Assessment of technical condition demonstrated by gas turbine blades.... Ocena stanu topatek turbiny gazowej metoda przetwarzania obrazów ....

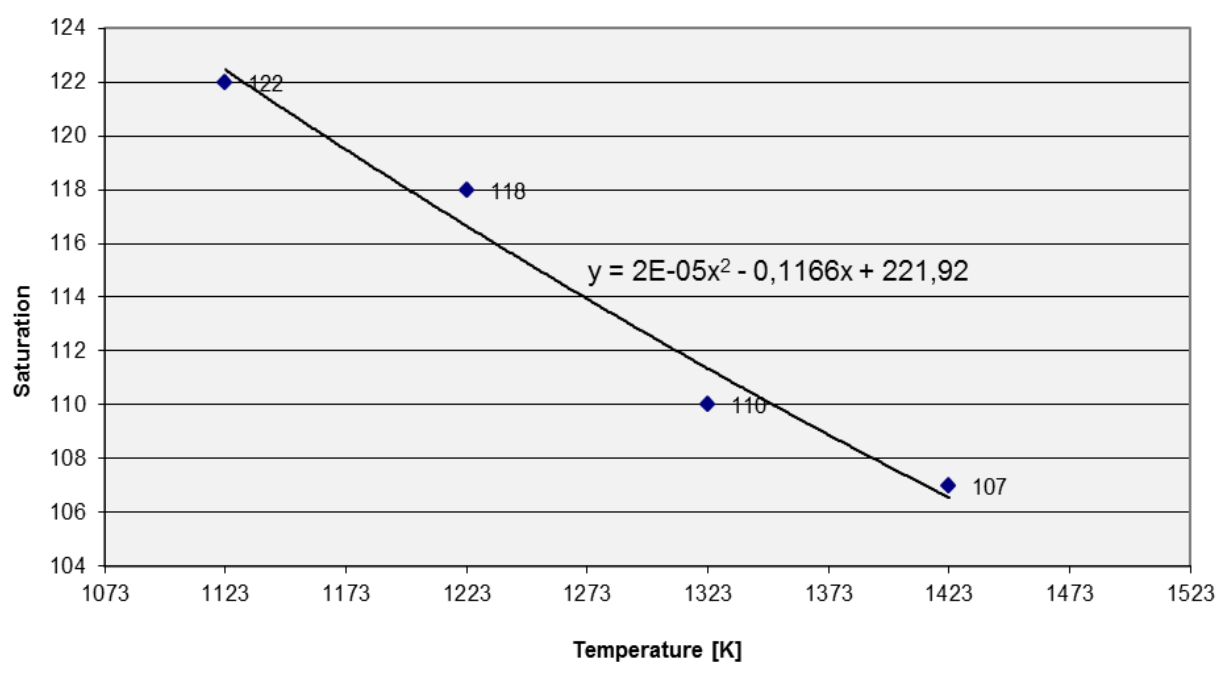

Fig. 5 The values for the position for the maximum amplitude value of the greyscale balance on the blade surface after heating at presence of exhaust gas fumes

\section{Metallographic investigations}

The metallographic tests carried out for blades after heating them at various temperatures demonstrated that high temperatures affect alterations of microstructures, both in the coating later and the EI-867 WD superalloy of the blade body itself. The temperature growth entails gradual increase of the aluminum coating thickness (Fig. 6), which is associated with the reduced heat resistance of blades. Expansion of the alloy grains by as much as $50 \%$ is observed (Fig. 7), which adversely affects its mechanical properties $[1,5]$. The most substantial alterations occur in the reinforcing $\gamma^{\prime}$ phase, where the overall structure of that phase is modified (Fig. 8). The temperature of $1123 \mathrm{~K}$ is conducive to the growth of small particles within that phase. In turn, at the temperature of $1423 \mathrm{~K}$ the particles with the largest initial dimensions subject to coagulation, which leads to formation of very large grains. It was found out that the temperature growth entails quantitative reduction of particles with the largest sizes as compared to the microstructure status of the material for both new blades and the ones subjected to the heating at the temperature of $1123 \mathrm{~K}$ (Fig. 9). At the same time the gradually increasing distance between the particles of the $\gamma^{\prime}$ phase is observed. The revealed expansion, recombination and corrugation of the $\gamma^{\prime}$ phase particles results in substantial deterioration of the heat resistance properties demonstrated by the alloy $[1,5]$. Since the alteration of the structure in the $\gamma^{\prime}$ phase lattice is usually adopted as the criteria for the blade material that approves the parts for further operation or 
not, it is possible to find out the position of the maximum amplitude of the greyscale saturation balance for the snapshots of blades and determine such an amplitude value that shall serve as the operability threshold for the turbine blades.

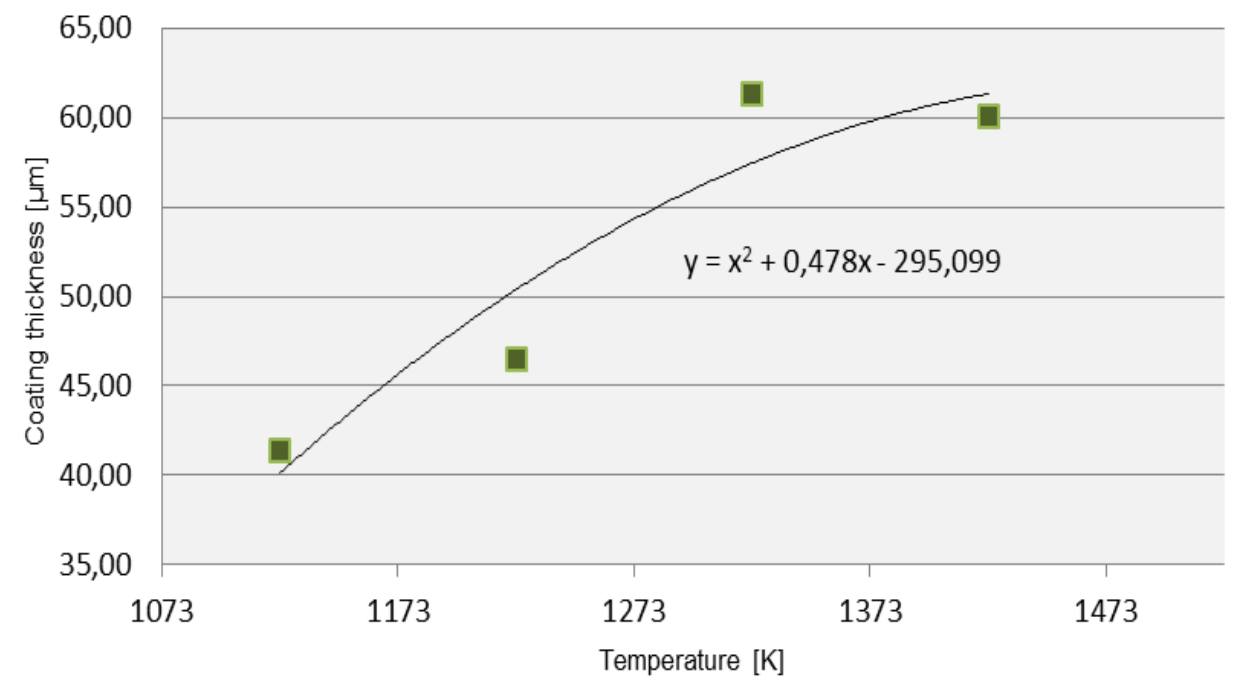

Fig. 6. Diagram with thickness variations of the aluminum coating on turbine blades after heating

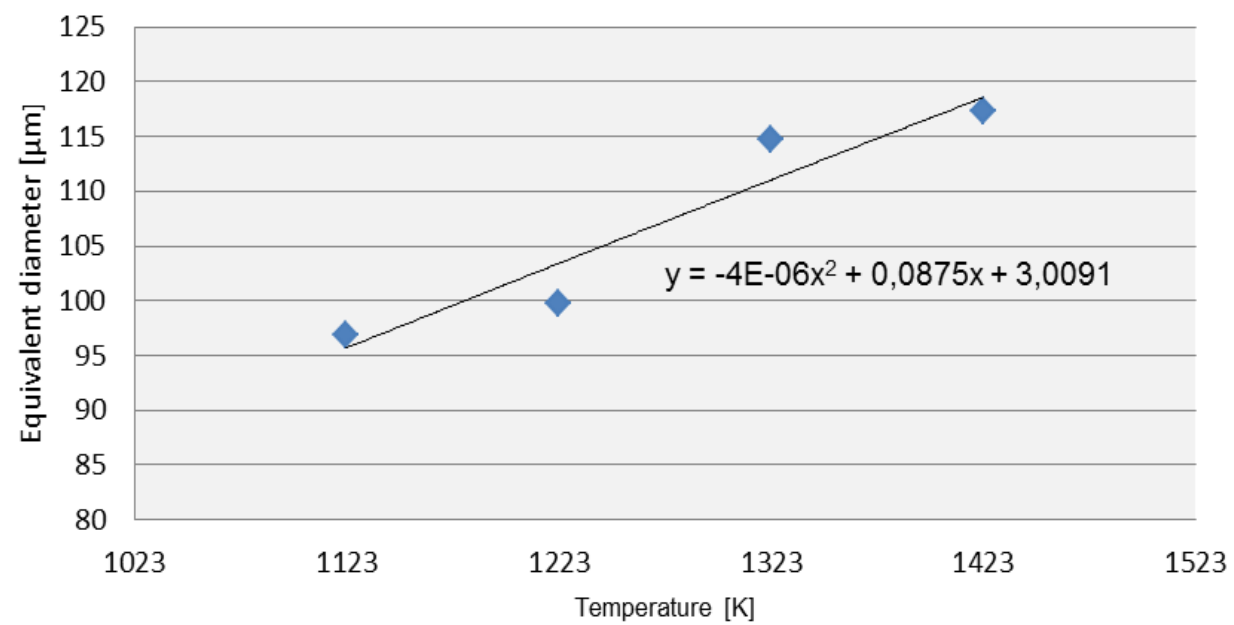

Fig. 7. Change of the average size of grains in the EI-867WD superalloy that is used to manufacture turbine blades. Differences are shown for new blades and the ones after heating at various temperatures, expressed as the diameter of an equivalent circle with its area equal to the average surface area of grains. 
Assessment of technical condition demonstrated by gas turbine blades....

Ocena stanu topatek turbiny gazowej metoda przetwarzania obrazów ....

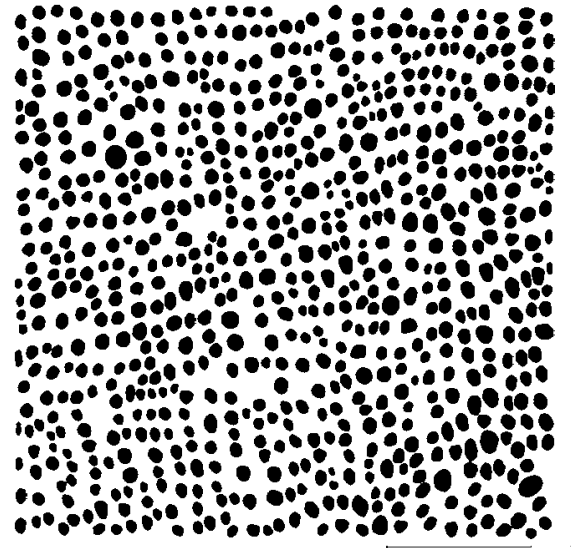

a)

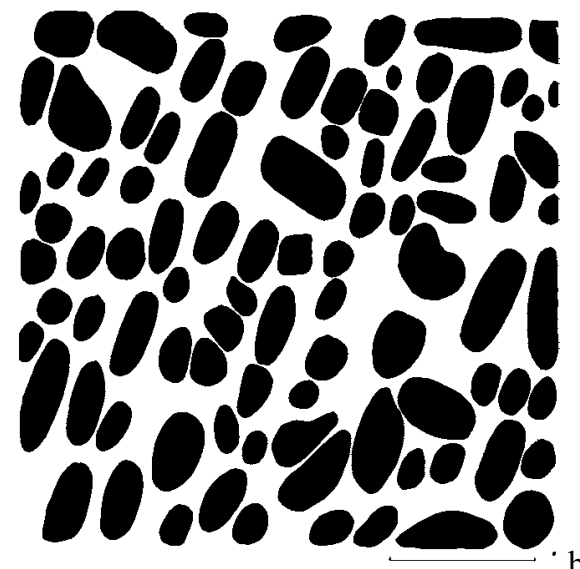

Fig. 8. Microstructure of turbine blades after heating at temperatures: a) - $1123 \mathrm{~K}$, b) - $1423 \mathrm{~K}$ (magn. x20000) - one can see coagulation, alteration of shapes and corrugation of the $\gamma$ ' phase formations.

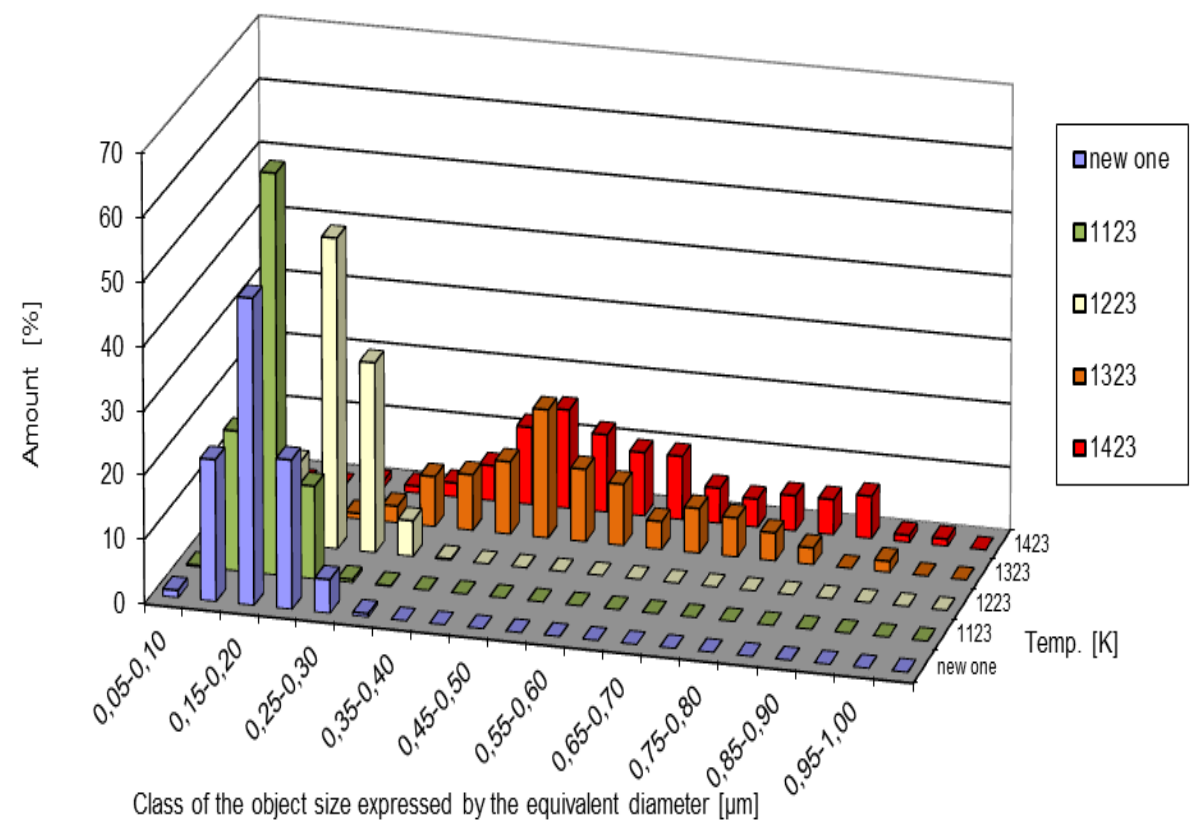

Fig. 9. Numbers of formations for individual size classes of the $\gamma$ ' phase particles in the material of blades - a new one and the ones after heating at temperatures from $1123 \mathrm{~K}$ to $1423 \mathrm{~K}$ 


\section{Conclusion}

The completed investigations on images for surface of turbine blades upon having them heated at presence of exhaust gas fumes demonstrated gradual decrease in the saturation value of greyscale shades in pace with growth of the heating temperature (Fig. 5). The comparative results from investigation of the material microstructure for turbine blades, both a new one and the ones after having them heated at various temperatures, made it possible to conclude that both the heating temperature and duration lead to alteration of the material microstructure. It is manifested by expansion of grains and modification of the reinforcing $\gamma^{\prime}$ phase (Fig. 7, 8). Growth of the heating temperature leads to quantitative reduction in numbers of the $\gamma$ ' particles with the largest sizes as compared to the microstructure status of the material for both new blades and the ones subjected to the heating at the temperature of $1123 \mathrm{~K}$. In addition, the average distance between particles of that phase permanently increases. Such phenomena as expansion, recombination and corrugation of the $\gamma^{\prime}$ phase particles were also revealed. When to assume alterations in the structure of the $\gamma^{\prime}$ phase lattice as a criterion that enables to approve or to reject the material for further operation one can define such a position of the maximum amplitude for saturation of greyscale shades that may serve as an threshold for operability status of turbine blades.

\section{References}

[1] Błachnio J.: Analysis of causes of decohesion of a gas turbine blade made of EI-867WD alloy. Aircraft Engineering and Aerospace Technology: An International Journal. Vol. 83 No 1, 2011, pp.14-20.

[2] Błachnio J., Pawlak W.J.: Damageability of gas turbine blades - evaluation of exhaust gas temperature in front of the turbine using a non-linear observer: An Advances in Gas Turbine Technology, InTech, 2011.

[3] Kułaszka A., Błachnio J.: Nieniszcząca metoda termograficzna do oceny stanu łopatek turbiny gazowej. Rozdział w monografii pt. „Problemy badań i eksploatacji techniki lotniczej”, Wydawnictwo ITWL, ss. 155-168, 2012. (The non-destructive thermographic method for status assessment of gas turbine blades. A chapter in the monograph book Issues related to investigation and operation of avionic technical means, ITWL Publishing House, pp. 155-168, 2012)

[4] Reports Air Force Institute of Technology, Warsaw, Poland, 2000-2012.

[5] Szczepanik R., Rządkowski R.: Badania dynamiki łopatek wirnikowych silników lotniczych w różnych warunkach eksploatacji. Monograficzna seria 
Assessment of technical condition demonstrated by gas turbine blades....

Ocena stanu łopatek turbiny gazowej metoda przetwarzania obrazów ....

wydawnicza Biblioteka Problemów Eksploatacyjnych. Wydawnictwo ITE PIB Warszawa - Radom 2012 (Investigation of dynamic properties demonstrated by rotor blades of avionic engines under various operating conditions; the monograph editorial series issued by the Library of Operation Issues. The scientific publishing house ITE-PIB, Warsaw - Radom, 2012)

[6] Bogdan M., Błachnio J.: A non-destructive method to assess condition of gas turbine blades, based on the analysis of blade-surface images. Russian Journal of Nondestructive Testing, Vol. 46, No. 11, 2010, pp. 860-866.

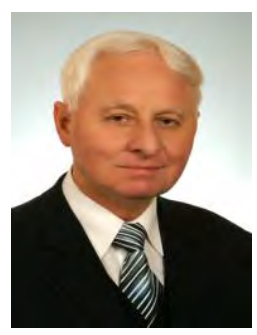

Józef Btachnio, Prof.D.Sc Eng. - Professor at ITWL (AFIT) Division for Aero-Engine.

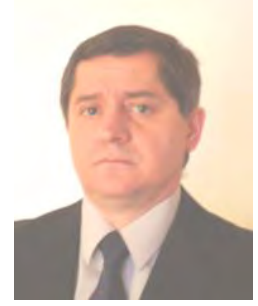

Jarostaw Spychata, PhD Eng. - Manager of Aero-Engine Division (AFIT)

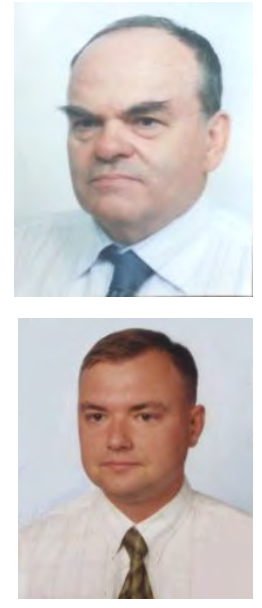

Wojciech Pawlak, PhD Eng. - Researcher at ITWL (AFIT) Division for Aero-Engines

Artur Kulaszka, MSc Eng. - Head of ITWL's (AFIT's) Laboratory for Monitoring Health of Turbomachinery 